\title{
AKTIVITAS ANTIBAKTERI GETAH PEPAYA KERING TERHADAP Staphylococcus aureus PADA DANGKE
}

\author{
[Antibacterial Activity of Dried Papaya Latex toward Staphylococcus aureus in Dangke] \\ Rifah Hestyani Arum ${ }^{11}$, Budiatman Satiawihardja ${ }^{1,2)}$ dan Harsi D. Kusumaningrum ${ }^{1,2,3)^{*}}$ \\ 1) Program Studi Ilmu Pangan, Institut Pertanian Bogor, Bogor \\ 2) Departemen IImu dan Teknologi Pangan, Fakultas Teknologi Pertanian, Institut Pertanian Bogor, Bogor \\ 3) Southeast Asian Food and Agricultural Science and Technology (SEAFAST) Center, Bogor
}

Diterima 19 November 2013 / Disetujui 12 Mei 2014

\begin{abstract}
Dangke is a traditional milk curd product, made by coagulation of milk using fresh papaya latex. This product is usually kept at room temperature $\left(27-30^{\circ} \mathrm{C}\right)$ until consumption. Dried papaya latex was used in this study to produce dangke, and its effect to $\mathrm{S}$. aureus was determined by direct contact in TSB and dangke. Fresh papaya latex was dried using vacuum oven at $50-55^{\circ} \mathrm{C}$ for 22 hours. Dried papaya latex at a concentration of $2.7 \times 10^{-3} \mathrm{~g} / 100 \mathrm{~mL}$ could reduce S. aureus approximately 1 log CFU/mL in TSB after 24 hours. Dried papaya latex and papain could maintain the $S$. aureus number in dangke within 24 hours storage at room temperature. The antibacterial activity of non-proteolytic compound of papaya latex, i.e ethanolic extract of papaya latex was determined by macrodilution method, resulted an the MIC 90 of $8 \mathrm{mg} / \mathrm{mL}$. The cell membrane leakage after exposure was detected by measuring the optical density of bacterial supernatant at $260 \mathrm{~nm}$. The result showed that exposure to increasing antibacterial concentration resulted in increasing of optical density of $S$. aureus supernatant, indicating that the antibacterial caused the $S$. aureus membrane leakage. Fluorescence microscopy imaging showed that $S$. aureus exposure to antibacterial caused membrane leakage thus gave Propidium lodide (PI) chance to penetrate into the cell, as indicated by changing of fluorescence color from green to red.
\end{abstract}

Keywords: cell membrane leakage, dangke, dried papaya latex

\section{ABSTRAK}

Dangke merupakan produk curd susu tradisional yang dibuat melalui proses koagulasi susu menggunakan getah pepaya. Produk ini biasanya disimpan pada suhu ruang $\left(27-30^{\circ} \mathrm{C}\right)$ hingga akan dikonsumsi dan mampu bertahan selama kurang lebih 24 jam. Getah pepaya pada penelitian ini digunakan untuk membuat dangke dan efeknya terhadap $S$. aureus ditentukan dengan menggunakan metode kontak pada media Trypticase Soy Broth (TSB) dan dangke. Getah pepaya segar dikeringkan dengan menggunakan oven vakum pada suhu $50-55^{\circ} \mathrm{C}$ selama 22 jam. Getah pepaya kering dengan konsentrasi $2.7 \times 10^{-3} \mathrm{~g} / 100 \mathrm{~mL}$ mampu menurunkan jumlah $\mathrm{S}$. aureus sebanyak 1 log $\mathrm{CFU} / \mathrm{mL}$ setelah 24 jam. Getah pepaya kering dan papain menunjukkan kemampuan mempertahankan jumlah $S$. aureus pada dangke selama penyimpanan 24 jam pada suhu ruang. Aktivitas antibakteri komponen non-proteolitik dari getah papaya, seperti ekstrak etanol getah pepaya ditentukan dengan menggunakan metode macrodilution, diperoleh nilai KHMgo sebesar $8 \mathrm{mg} / \mathrm{mL}$. Kebocoran membran sel setelah pemaparan dengan antibakteri dideteksi dengan mengukur absorbansi supernatan S. aureus pada panjang gelombang $260 \mathrm{~nm}$. Hasil yang diperoleh menunjukkan peningkatan konsentrasi antibakteri mengakibatkan peningkatan absorbansi supernatan yang mengindikasikan antibakteri mampu mengakibatkan kebocoran pada membran $S$. aureus. Pengamatan dengan menggunakan mikroskop fluoresens memperlihatkan terjadi perubahan warna fluoresensi yang dihasilkan oleh $S$. aureus akibat masuknya propidium iodida (PI) ke dalam sel melalui membran yang bocor akibat aktivitas antibakteri.

Kata kunci: dangke, getah pepaya kering, kebocoran membran sel

\section{PENDAHULUAN}

Dangke merupakan salah satu produk pangan tradisional yang berasal dari daerah Enrekang, Sulawesi Selatan yang mirip dengan tahu susu. Dangke dibuat dengan menggumpalkan susu menggunakan getah pepaya, yang mengakibatkan perubahan konformasi pada struktur tiga dimensi protein karena aktivitas proteolitiknya (Geantaresa et al. 2010). Dangke yang disimpan pada suhu ruang $\left(27-30^{\circ} \mathrm{C}\right)$ berpotensi dapat terkontaminasi oleh $S$. aureus, mengingat susu pasteurisasi

*Penulis Korespondensi:

E-mail: h_kusumaningrum@ipb.ac.id; Telp: 0251-8626725 sebagai bahan baku dangke dapat terkontaminasi oleh $S$. aureus dengan jumlah rata-rata $3.5 \times 10^{3} \mathrm{CFU} / \mathrm{mL}$ sebagimana dilaporkan oleh De Olievera et al. (2011).

Getah pepaya yang digunakan pada pembuatan dangke, selain memiliki aktivitas proteolitik juga dilaporkan memiliki kemampuan sebagai bahan antibakteri dan anti-inflamasi (Ashok et al. 2011; Aravind et al. 2013). Aktivitas antibakteri getah pepaya dan papain dari getah pepaya telah dilaporkan oleh Seenivasan et al. (2010) yang menguji aktivitas antibakteri papain terhadap beberapa bakteri dan fungi pada media Mueller Hinton Agar (MHA). Selain itu, ekstrak petroleum eter dan metanol getah pepaya juga menunjukkan kemampuan menghambat pertumbuhan $E$. coli, $S$. aureus, dan $P$. aeruginosa 
(Ashok et al. 2011). Pengujian aktivitas antibakteri getah tanaman selama ini banyak dilakukan pada media MHA (Aref et al. 2010; Arekemase et al. 2011). Pada penelitian ini selain dilakukan pengujian sifat antimikroba getah pepaya pada media pertumbuhan juga dilakukan pengujian pada produk pangan, yaitu dangke.

Kemampuan antibakteri dalam menghambat pertumbuhan bakteri dapat berlangsung melalui beberapa mekanisme, salah satunya adalah mengakibatkan gangguan pada membran sel bakteri (Cowan et al. 1999). Salah satu metode yang dapat digunakan adalah dengan mengamati efek kebocoran membran yang mengakibatkan terlepasnya material sitoplasma, khususnya senyawa-senyawa dengan berat molekul rendah dan komponen penyusun asam nukleat (Oonmetta-aree et al. 2006). Pelepasan material sitoplasma akibat kebocoran membran ini dapat diperiksa dengan mengukur absorbansi supernatan pada panjang gelombang $260 \mathrm{~nm}$ (Liu et al. 2004). Selain itu, metode lain yang dapat dilakukan adalah dengan pengamatan menggunakan mikroskop fluoresensi dengan memanfaatkan DNA probe sebagai penanda. Penelitian ini bertujuan untuk mengetahui aktivitas antibakteri getah pepaya pada dangke selama penyimpanan pada suhu ruang $\left(27-30^{\circ} \mathrm{C}\right.$ serta pengaruh getah pepaya terhadap membran Staphylococcus aureus.

\section{BAHAN DAN METODE}

\section{Bahan}

Getah pepaya yang digunakan pada penelitian ini diperoleh dari buah pepaya varietas Calina IPB (University Farm IPB) yang dikumpulkan dengan cara menoreh buah dengan kedalaman kurang lebih 2 sampai $3 \mathrm{~mm}$. Getah selanjutnya dikeringkan menggunakan oven vakum pada suhu $50-55^{\circ} \mathrm{C}$ selama 22 jam, kemudian digerus hingga menjadi bubuk dan ditentukan aktivitas proteolitiknya berdasarkan metode Bergmeyer (1984).

\section{Persiapan papain dari getah pepaya (Modifikasi Nitsawang et al. 2006)}

Getah pepaya segar dihomogenkan menggunakan buffer fosfat $\mathrm{pH}$ 8. Larutan yang diperoleh kemudian dibuat menjadi pH 5 dengan menggunakan $\mathrm{HCl}$ (Merck, USA) $6 \mathrm{M}$ lalu diaduk selama 15 menit pada suhu $4^{\circ} \mathrm{C}$. Filtrat dan bagian yang tidak larut dipisahkan dengan penyaringan menggunakan kertas saring Whatman no. 1. Protease yang larut pada filtrat dipresipitasi menggunakan etanol 96\% dengan perbandingan 1:6 (v/v). Endapan yang diperoleh dipisahkan dengan sentrifugasi (Hermle, Jerman) pada kecepatan $4000 \mathrm{rpm}$ pada suhu $4^{\circ} \mathrm{C}$. Presipitat kemudian dikeringkan menggunakan oven vakum pada suhu $50^{\circ} \mathrm{C}$ hingga diperoleh papain kasar kering. Papain kasar yang diperoleh, dihitung rendemennya dan diukur aktivitas proteolitiknya dengan metode Bergemeyer (1984).

\section{Persiapan ekstrak etanol getah pepaya (Modifikasi Wang et al. 2008)}

Komponen bioaktif non-proteolitik getah pepaya diperoleh melalui proses ekstraksi menggunakan pelarut etanol.
Modifikasi yang dilakukan dari penelitian Wang et al. 2008 adalah konsentrasi etanol yang digunakan sebesra 96\%. Campuran getah pepaya kering dan etanol dengan perbandingan 1:20 (b/v) diultrasonikasi menggunakan BRANSONIC Ultrasonic cleaner 8510E-MTH, USA selama 20 menit. Larutan getah yang telah melalui proses ultrasonikasi disaring menggunakan kertas Whatman no.1. Filtrat kemudian dipekatkan dengan evaporasi menggunakan rotary evaporator (BUCHI, Switzerland) pada suhu $40^{\circ} \mathrm{C}$. Filtrat pekat kemudian dihembus dengan gas nitrogen hingga diperoleh berat konstan untuk mendapatkan ekstrak etanol kering.

\section{Persiapan kultur S. aureus (Oonmetta-aree et al. 2006)}

Kultur S. aureus yang berada dalam media Trypticase Soy Agar (TSA) miring diinokulasikan ke media Brain Heart Infution Broth (BHIB) lalu diinkubasi selama 18 sampai 24 jam pada suhu $37^{\circ} \mathrm{C}$. Suspensi bakteri yang diperoleh kemudian digores pada media TSA di cawan lalu diinkubasi selama 48 jam pada suhu $37^{\circ} \mathrm{C}$. Koloni identik dan tunggal diambil lalu diinkubasikan ke dalam $10 \mathrm{~mL}$ media TSB dan diinkubasi selama 18 sampai 24 jam pada suhu $37^{\circ} \mathrm{C}$. Penghitungan jumlah koloni dilakukan berdasarkan metode BAM (2003). Suspensi S. aureus pada media TSB digunakan sebagai kultur kerja untuk pengujian aktivitas antibakteri getah pepaya kering, papain, dan ekstrak etanol getah pepaya.

\section{Pengujian aktivitas antibakteri getah pepaya pada media pertumbuhan (Modifikasi Eshamah et al. 2013)}

Aktivitas antibakteri getah pepaya pada media pertumbuhan diuji dengan menggunakan metode kontak pada media cair. Kontak antara bakteri dengan komponen antibakteri dilakukan pada tabung reaksi, berbeda dengan Eshamah et al. 2013 yang melakukan kontak pada cawan petri. Getah pepaya kering atau papain dimasukkan ke dalam $2 \mathrm{~mL}$ TSB (Oxoid, UK) hingga diperoleh konsentrasi yang setara dengan konsentrasi getah pepaya segar yang digunakan pada pembuatan dangke berdasarkan aktivitas proteolitiknya $\left(2.7 \times 10^{-3} \mathrm{~g} / 100 \mathrm{~mL}\right.$ untuk getah pepaya kering dan $0.1 \times 10^{-3} \mathrm{~g} / 100 \mathrm{~mL}$ untuk papain). Sebanyak $20 \mu \mathrm{L}$ S. aureus dengan konsentrasi $10^{6} \mathrm{CFU} / \mathrm{mL}$ ditambahkan ke dalam $1.98 \mathrm{~mL}$ media sehingga diperoleh konsentrasi sekitar $10^{4} \mathrm{CFU} / \mathrm{mL}$ kemudian diinkubasi dengan inkubator bergoyang selama 24 jam pada suhu $37^{\circ} \mathrm{C}$. Penurunan jumlah $S$. aureus akibat aktivitas antimikroba ditentukan dengan menumbuhkan bakteri yang telah dipaparkan dengan antimikroba selama 24 jam pada media TSA (Oxoid, UK) dan dihitung dengan menggunakan metode BAM (2003).

\section{Pengujian penghambatan $S$. aureus pada dangke oleh getah pepaya dan papain}

Dangke dibuat dengan memanaskan susu sapi segar hingga dicapai suhu $63^{\circ} \mathrm{C}$ selama 10 menit. Setelah suhu diturunkan hingga $50^{\circ} \mathrm{C}, 2.7 \times 10^{-3} \mathrm{~g} / 100 \mathrm{~mL}$ getah pepaya kering atau $0.1 \times 10^{-3} \mathrm{~g} / 100 \mathrm{~mL}$ papain ditambahkan ke dalam $100 \mathrm{~mL}$ susu. $\mathrm{CaSO}_{4} 1 \%$ juga digunakan sebagai koagulan untuk membuat dangke, sebagai kontrol negatif. Pemanasan terus dilanjutkan dengan pengadukan hingga protein susu menggumpal dan terjadi pemisahan antara curd dan whey. Curd 
disaring dan dipadatkan hingga air yang ada pada curd tidak tersisa lagi. Dangke disimpan pada jar steril selama 48 jam pada suhu ruang. Jumlah $S$. aureus yang tumbuh pada dangke dihitung pada $0,6,24$, dan 48 jam selama penyimpanan dangke pada suhu ruang berdasarkan metode BAM (2003).

\section{Pengujian aktivitas antibakteri ekstrak etanol getah pepaya}

Pengujian awal aktivitas antibakteri ekstrak etanol getah pepaya dilakukan dengan menentukan zona hambat menggunakan metode difusi sumur berdasarkan Baskaran et al. (2012). Suspensi S. aureus dengan konsentrasi $10^{8} \mathrm{CFU} / \mathrm{mL}$ disebarkan menggunakan cotton bud steril pada media Mueller Hinton Agar (Oxoid, UK) lalu dibuat sumur dengan cork borer steril berdiameter $4 \mathrm{~mm}$. Sebanyak $20 \mu \mathrm{L}$ ekstrak etanol getah pepaya dengan konsentrasi masing-masing 100, 32, 16, 8, and $4 \mathrm{mg} / \mathrm{mL}$ diteteskan ke sumur. Cawan kemudian didiamkan selama kurang lebih satu jam pada suhu ruang $\left(27-30^{\circ} \mathrm{C}\right)$ untuk memberi kesempatan antibakteri berdifusi ke agar lalu diinkubasi pada suhu $37^{\circ} \mathrm{C}$ selama 24 jam. Zona penghambatan ekstrak etanol getah pepaya yang ditandai dengan terbentuknya zona bening diukur diameternya.

Aktivitas antibakteri ekstrak etanol getah pepaya selanjutnya diuji dengan menentukan konsentrasi hambat minimum (KHM9o) menggunakan metode pengenceran makro (macrodilution) berdasarkan Cosentino et al. (1999). KHM90 merupakan konsentrasi dimana antimikroba mampu menurunkan jumlah bakteri sebanyak $90 \%$ atau 1 logaritma. Senyawa antibakteri dimasukkan ke dalam tabung berisi TSB sebanyak 2 $\mathrm{mL}$ dan dibuat seri pengenceran dua kali, sehingga diperoleh konsentrasi antibakteri masing-masing 16, 8, 4, dan $2 \mathrm{mg} / \mathrm{mL}$. Masing-masing tabung kemudian ditambahkan $S$. aureus dengan konsentrasi $10^{6} \mathrm{CFU} / \mathrm{mL}$ sebanyak $200 \mu \mathrm{L}$ sehingga diperoleh konsentrasi bakteri $10^{5} \mathrm{CFU} / \mathrm{mL}$. Inkubasi dilakukan dengan menggunakan inkubator bergoyang pada suhu $37^{\circ} \mathrm{C}$ selama 24 jam. $\mathrm{KHM}_{90}$ ditentukan dengan menghitung penurunan jumlah $S$. aureus,

\section{Pengujian pelepasan material sitoplasma akibat kerusakan membran (Modifikasi Oonmetta-aree et al. 2006)}

Getah pepaya kering atau papain ditambahkan ke dalam 1 $\mathrm{mL}$ suspensi bakteri hingga diperoleh konsentrasi yang setara dengan setengah, satu, dua, dan tiga kali konsentrasi getah pepaya segar pada pembuatan dangke berdasarkan aktivitas proteolitik $\left(2.7 \times 10^{-3} \mathrm{~g} / 100 \mathrm{~mL}\right.$ untuk getah pepaya kering dan $0.1 \times 10^{-3} \mathrm{~g} / 100 \mathrm{~mL}$ untuk papain). Ekstrak etanol getah pepaya ditambahkan ke $1 \mathrm{~mL}$ suspensi bakteri hingga diperoleh konsentrasi yang setara dengan setengah, satu, dan dua kali nilai $\mathrm{KHM}_{90}$ ekstrak etanol getah pepaya. Pemaparan dilakukan selama 2 jam pada suhu $37^{\circ} \mathrm{C}$. Kebocoran material sitoplasma ditentukan dengan mengukur material sel yang ada di dalam supernatan menggunakan spektrofotometer (Shimadzu UV 1800, Jepang) pada panjang gelombang $260 \mathrm{~nm}$.

\section{Pengamatan kerusakan membran sel dengan mikroskop fluoresens (Modifikasi Berney et al. 2007) \\ Pengujian pengaruh antibakteri terhadap $S$. aureus dilakukan dengan cara sel bakteri yang telah dipisahkan dengan media dicuci sebanyak dua kali dengan $\mathrm{NaCl} 0.85 \%$ steril lalu}

diresuspensi menggunakan $\mathrm{NaCl}$ 0.85\% dan dikonsentrasikan hingga konsentrasi kira-kira $10^{8} \mathrm{CFU} / \mathrm{mL}$. Getah pepaya kering atau papain ditambahkan ke $1 \mathrm{~mL}$ suspensi bakteri hingga diperoleh konsentrasi yang setara dengan konsentrasi getah pepaya segar pada pembuatan dangke berdasarkan aktivitas proteolitik $\left(2.7 \times 10^{-3} \mathrm{~g} / 100 \mathrm{~mL}\right.$ untuk getah pepaya kering dan $0.1 \times 10^{-3} \mathrm{~g} / 100 \mathrm{~mL}$ untuk papain). Ekstrak etanol getah pepaya ditambahkan ke $1 \mathrm{~mL}$ suspensi bakteri hingga diperoleh konsentrasi yang setara dengan nilai KHM. Pemaparan dilakukan selama 2 jam pada suhu $37^{\circ} \mathrm{C}$. Pewarnaan dilakukan dengan menggunakan $200 \mu \mathrm{L}$ SYBR Green (KAPA Biosystem, USA) dan $200 \mu \mathrm{L}$ propidium iodida $0.2 \mathrm{mg} / \mathrm{mL}$ (Invitrogen, UK) lalu diinkubasi selama 15 menit pada suhu ruang dan kondisi gelap, kemudian diamati menggunakan mikroskop fluoresens (Olympus $\mathrm{CH} 30$, Jepang). Sel dengan membran yang utuh menghasilkan fluoresensi hijau, sedangkan sel dengan membran yang rusak menghasilkan fluoresensi merah. Fluoresensi merah terbentuk pada eksitasi maksimum $535 \mathrm{~nm}$ dan emisi maksimum $617 \mathrm{~nm}$.

\section{HASIL DAN PEMBAHASAN}

\section{Karakteristik getah pepaya segar, getah pepaya kering dan papain}

Karakteristik getah pepaya segar, getah pepaya kering, dan papain disajikan pada Tabel 1. Kadar air getah pepaya segar adalah sebesar $81 \%$ (basis basah), hal ini sesuai dengan yang dilaporkan oleh El Moussaoui et al. (2001) yaitu kadar air getah pepaya segar adalah sekitar $85 \%$. Aktivitas proteolitik getah pepaya kering adalah $723 \pm 20 \mathrm{U} / \mathrm{g}$ per berat kering enzim dan aktivitas proteolitik papain adalah $678 \pm 5.4 \mathrm{U} / \mathrm{g}$ per berat kering enzim. Getah pepaya segar memiliki aktivitas proteolitik sebesar $371 \pm 2 \mathrm{U} / \mathrm{g}$ per berat basah enzim, Nitsawang et al. (2006) melaporkan aktivitas proteolitik getah pepaya segar varietas Thai adalah sebesar $529 \pm 162 \mathrm{U} / \mathrm{g}$. Perbedaan aktivitas proteolitik yang diperoleh ini dipengaruhi oleh perbedaan jenis pepaya yang digunakan seperti yang dinyatakan oleh Chaiwut et al. (2007). Aktivitas proteolitik komponen getah pepaya pada penelitian ini diukur sebagai acuan untuk menyetarakan jumlah getah pepaya kering dan papain yang digunakan sebagai pengganti getah pepaya segar pada pembuatan dangke berdasarkan jumlah yang diaplikasikan di masyarakat.

Tabel 1. Karakteristik getah pepaya segar, getah pepaya kering, dan papain ${ }^{1)}$

\begin{tabular}{lcccc}
\hline Komponen & $\begin{array}{c}\text { Kadar Air } \\
(\%)\end{array}$ & $\begin{array}{c}\text { Rendemen } \\
(\%)\end{array}$ & $\begin{array}{c}\text { Aktivitas } \\
\text { Proteolitik } \\
(\mathrm{U} / \mathrm{g})^{2}\end{array}$ & $\begin{array}{c}\text { Aktivitas } \\
\text { Proteolitik } \\
(\mathrm{U} / \mathrm{g})^{3}\end{array}$ \\
\hline Getah segar & $81 \pm 0.3$ & - & $1944.9 \pm 10$ & $371 \pm 2$ \\
Getah kering & $9.8 \pm 0.2$ & $17.1 \pm 1.26$ & $722.5 \pm 20$ & $652 \pm 18$ \\
Papain & $3.4 \pm 0.1$ & $1.5 \pm 0.28$ & $687.0 \pm 5$ & $656 \pm 5$ \\
\hline
\end{tabular}

Keterangan: 1) Data disajikan dalam rata-rata \pm SD; 2) Aktivitas per berat kering getah dan papain; 3) Aktivitas per berat basah getah dan papain

\section{Aktivitas antibakteri getah pepaya dan papain pada media pertumbuhan dan dangke}

Gambar 1 menunjukkan getah pepaya kering mampu menurunkan jumlah $S$. aureus sebanyak 1 log dari jumlah awal 
(dari $3.0 \times 10^{3}$ menjadi $2.5 \times 10^{2} \mathrm{CFU} / \mathrm{mL}$ ). Papain cenderung mampu mempertahankan jumlah $S$. aureus (dari $2.7 \times 10^{3}$ menjadi $4.7 \times 10^{3} \mathrm{CFU} / \mathrm{mL}$ ) setelah 24 jam pada media pertumbuhan. Hasil ini mengindikasikan getah pepaya memiliki kemampuan penghambatan yang lebih tinggi dibanding papain. Kemampuan getah pepaya yang lebih tinggi ini dipengaruhi oleh kandungan getah pepaya yang lebih kompleks bila dibandingkan papain yang telah dipisahkan dari komponen aktif lainnya (Chaiwut et al. 2007). Konsentrasi getah pepaya kering dan papain yang digunakan pada penelitian ini berturut-turut adalah $2.7 \times 10^{-3}$ dan $0.1 \times 10^{-3} \mathrm{~g} / 100 \mathrm{~mL}$. Konsentrasi ini setara dengan jumlah getah pepaya segar yang digunakan pada pembuatan dangke di masyarakat berdasarkan aktivitas proteolitik.

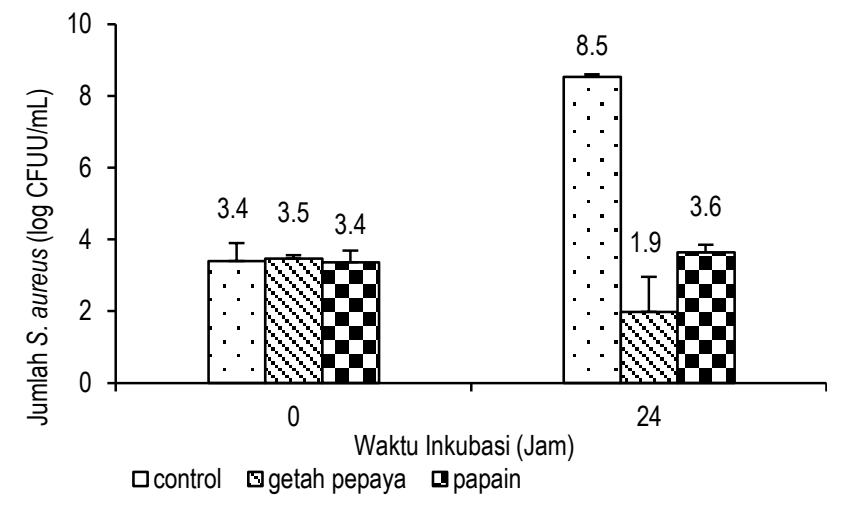

Gambar 1. Aktivitas antibakteri getah pepaya kering dan papain terhadap S. aureus pada media TSB selama 24 jam

Hasil yang ditunjukkan pada Gambar 2 memperlihatkan getah pepaya kering dan papain mampu menghambat pertumbuhan $S$. aureus pada penyimpanan dangke selama 6 hingga 24 jam pada suhu ruang $\left(27-30^{\circ} \mathrm{C}\right)$. Jumlah $\mathrm{S}$. aureus mengalami peningkatan setelah disimpan selama 24 hingga 48 jam dengan kecepatan yang sama seperti pada perlakuan kontrol $\mathrm{CaSO}_{4}$. Hasil yang diperoleh ini menunjukkan getah pepaya kering dan papain yang digunakan sebagai bahan penggumpal pada pembuatan dangke memiliki kemampuan menghambat laju pertumbuhan $S$. aureus yang mengontaminasi produk ini. Dangke merupakan produk berbasis susu yang cenderung berisiko terkontaminasi oleh $S$. aureus. De Olievera et al. (2011) menemukan kontaminasi $S$. aureus pada beberapa produk susu pasteurisasi. S. aureus cenderung mengontaminasi makanan jadi yang diolah dan ditangani secara tidak higienis (Singh et al. 2010).

Aktivitas antibakteri getah pepaya kering pada dangke lebih rendah bila dibandingkan aktivitasnya pada media pertumbuhan. Getah pepaya kering pada dangke tidak dapat mereduksi jumlah $S$. aureus seperti pada media pertumbuhan yang diperlihatkan pada Gambar 1 dan 2. Hal ini diduga karena bahan pangan merupakan bahan yang kompleks dan mengandung beberapa macam komponen gizi yang diduga dapat mendukung pertumbuhan $S$. aureus dan menghambat aktivitas antibakteri. Selain itu, juga diduga bahan antibakteri berikatan secara tidak dapat balik dengan sel bakteri, partikulat, dan komponen bahan pangan sehingga sisi aktif bahan antibakteri ini kehilangan aktivitasnya terhadap sel lain yang belum berikatan (Rhoades et al. 2000).

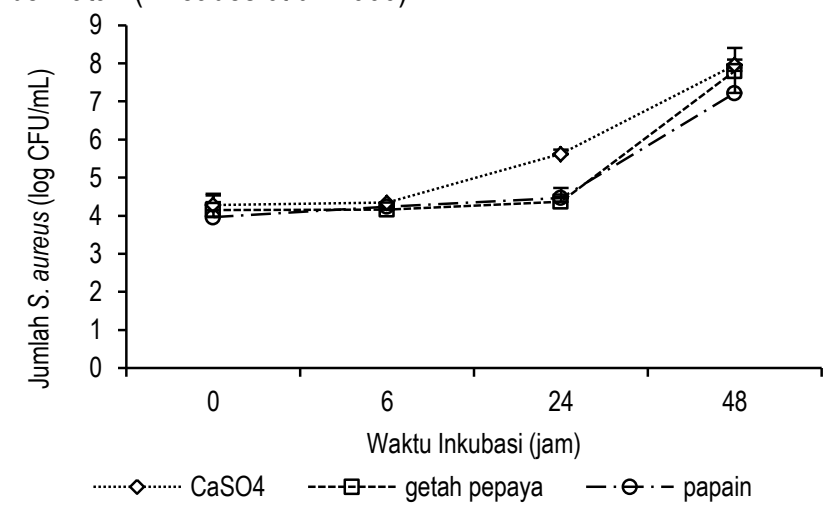

Gambar 2. Aktivitas antibakteri getah pepaya kering dan papain pada dangke selama penyimpanan 48 jam pada suhu ruang $\left(27-30^{\circ} \mathrm{C}\right)$

\section{Aktivitas antibakteri ekstrak etanol getah pepaya}

Konsentrasi terendah yang mampu menghambat pertumbuhan yang berbeda nyata adalah $16 \mathrm{mg} / \mathrm{mL}$ yaitu sebesar $0.76 \mathrm{~mm}$ (data tidak ditampilkan). Konsentrasi ini selanjutnya digunakan pada penentuan KHM9o. Akujobi et al. (2010) menggunakan ekstrak air pepaya muda $100 \%$ dan memperoleh zona hambat sebesar $26 \mathrm{~mm}$ pada suhu $30^{\circ} \mathrm{C}$. Pada pengujian etanol dan DMSO yang digunakan sebagai kontrol negatif tidak menunjukkan penghambatan terhadap $S$. aureus. Hasil yang diperoleh menunjukkan nilai KHMgo ekstrak etanol getah pepaya sebesar $8 \mathrm{mg} / \mathrm{mL}$ (Gambar 3).

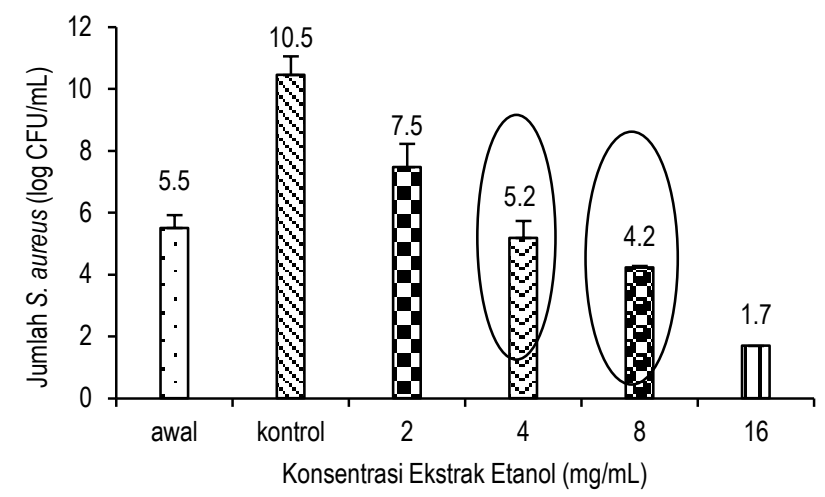

Keterangan: Gambar batang yang pertama menunjukkan jumlah awal S.aureus yang digunakan untuk pengujian

Gambar 3. Penghambatan ekstrak etanol getah pepaya terhadap $S$. aureus pada media TSB setelah inkubasi 24 jam

Baskaran et al. (2012) melaporkan komponen fitokimia yang diekstraksi daun pepaya menunjukkan efek penghambatan terhadap beberapa bakteri. Hasil lain yang dilaporkan oleh Ashok et al. (2011) menunjukkan kemampuan ekstrak petroleum eter dan metanol getah pepaya menghambat pertumbuhan $E$. coli, $P$. aeruginosa, dan S. aureus. Sifat antibakteri ektrak bagian tanaman getah pepaya ini dipengaruhi oleh kandungan senyawa aktif yang dikandung oleh ekstrak getah pepaya yaitu flavonoid, alkaloid, tanin, triterpenoid, seroid, dan saponin (Krishna et al. 2008). Adejuwon et al. (2011) melapor- 
kan nilai $\mathrm{KHM}_{90}$ ekstrak metanol dan air akar pepaya yang mengandung flavonoid, alkaloid, tannin, dan glikosida masingmasing adalah $2.0 \mathrm{mg} / \mathrm{mL}$ dan $8.0 \mathrm{mg} / \mathrm{mL}$.

\section{Pengaruh antibakteri terhadap membran sel $\mathbf{S}$. aureus}

Hasil pengukuran absorbansi untuk masing-masing perlakuan yang diperlihatkan pada Gambar 4 menunjukkan perubahan nilai absorbansi seiring perubahan konsentrasi antibakteri yang digunakan, Perubahan nilai absorbansi supernatan menandakan terjadi perubahan jumlah komponen yang mampu menyerap cahaya pada panjang gelombang 260 $\mathrm{nm}$ yang dilepaskan dari dalam sel akibat aktivitas antibakteri. Penurunan nilai absorbansi mengindikasikan senyawa antibakteri tidak mengakibatkan efek kebocoran membran sel lagi kemungkinan disebabkan oleh efek subletal yang memberikan kemampuan bagi bakteri untuk melakukan osmoregulasi terhadap senyawa toksik (Carson et al. 2002). Hasil ini mengindikasikan getah pepaya kering, papain, dan ekstrak etanol mampu mengakibatkan kebocoran membran sel pada konsentrasi tertentu.

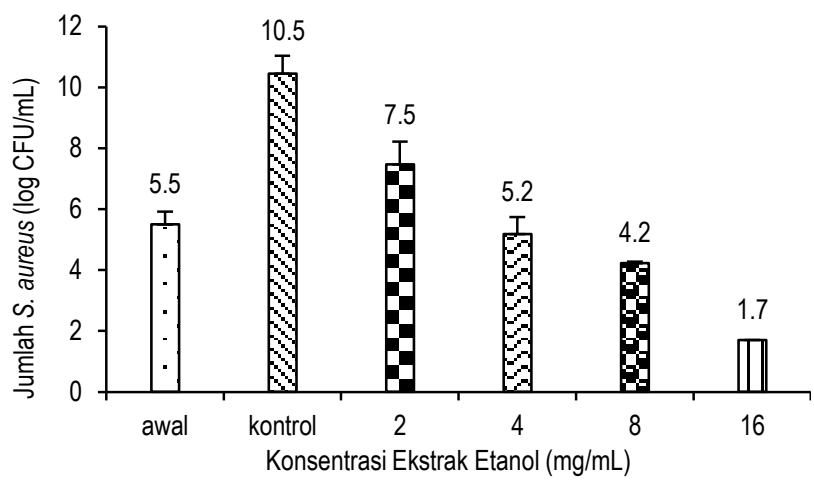

Keterangan: Konsentrasi adalah kelipatan jumlah getah pepaya kering dan papain yang digunakan pada pembuatan dangke dan nilai KHM ekstrak etanol getah pepaya

Gambar 4. Absorbansi $260 \mathrm{~nm}$ supernatan S. aureus setelah pemaparan dengan bahan antibakteri selama 2 jam

Metode deteksi lain yang digunakan pada penelitian ini adalah dengan pengamatan menggunakan mikroskop fluoresens. Gambar 5a menunjukkan sel utuh yang diwarnai dengan SYBR Green dan PI menghasilkan fluoresensi hijau. SYBR Green merupakan pewarna DNA yang mampu berdifusi ke dalam sel sehingga mampu mewarnai sel baik yang memilik membran yang utuh maupun yang rusak. Broadaway et al. (2003) menggunakan SYBR Green untuk mendeteksi keberadaan bakteri dalam jumlah yang sedikit dengan cepat menggunakan laser-cytometry. Sel dengan membran yang rusak diperlihatkan pada Gambar 5b, warna merah dihasilkan dari ikatan antara pewarna PI dengan DNA. PI tidak mampu berdifusi ke dalam sel dengan membran utuh karena ukurannya yang besar (BM 668.4) sehingga hanya mampu masuk ke dalam sel bila terdapat bagian yang rusak pada membran (Giao et al. 2009), yang pada penelitian ini diakibatkan oleh aktivitas getah pepaya kering, papain, ekstrak etanol.

Sifat PI yang tidak mampu berdifusi melalui sel yang utuh dan hanya mampu masuk melalui membran yang mengalami kerusakan inilah yang dimanfaatkan pada pengujian untuk membedakan sel yang utuh dengan sel yang mengalami kebocoran. PI yang masuk ke dalam sel berikatan dengan komponen asam nukleat dan menghasilkan fluoresensi merah (Santo et al. 2011). Penggunaan PI sebagai pewarna untuk mendeteksi kerusakan sel telah dilakukan oleh Otto et al. (2010) yang menguji efek campuran mineral CB07 dan BY07 terhadap integritas membran $S$. aureus dan $E$. coli. PI yang masuk ke dalam sel akan menggantikan posisi pewarna lain dan menghilangkan efek fluoresensi yang dihasilkan oleh pewarna sebelumnya, yang dalam hal ini adalah SYBR Green, sehingga yang tampak di bawah mikroskop fluoresens adalah fluoresensi merah (Berney et al. 2007).

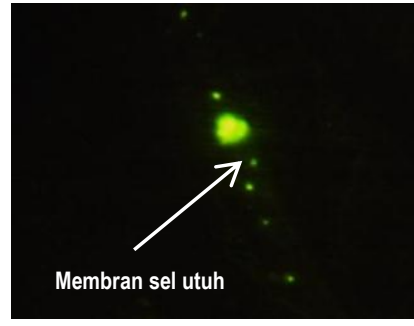

a

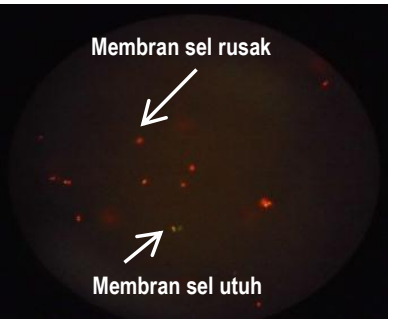

b
Gambar 5. Penampakan S. aureus setelah pemaparan dengan getah pepaya kering, papain, dan ekstrak etanol getah pepaya dengan konsentrasi 1 kali $\mathrm{KHM}_{90}$ selama 2 jam di bawah mikroskop fluoresens. (a) fluoresensi hijau dihasilkan oleh sel dengan membran yang utuh dan (b) fluoresensi merah dihasilkan oleh sel yang mengalami kebocoran membran

Getah pepaya kering mampu mengakibatkan kebocoran pada membran sel bakteri akibat aktivitas senyawa-senyawa aktif yang dikandungnya, antara lain adalah enzim papain, yang merupakan salah satu enzim proteolitik (El Moussaoui et al. 2001). Membran sel bakteri Gram positif dilapisi oleh dinding sel yang tersusun atas peptidoglikan dan mengandung GIcNAc, Nacetyl murmeric acid dan asam amino D- dan L- yang mampu berikatan dengan ion positif dari senyawa antibakteri. Protein yang menyusun membran sel bakteri inilah yang menjadi target kerja papain yang terdapat pada getah pepaya. Terganggunya struktur protein pada membran sel mengakibatkan gangguan permeabilitas membran sel seperti yang dilaporkan oleh Seenivasan et al. (2010). Hal ini dibuktikan dengan perubahan nilai absorbansi supernatan yang diperoleh setelah pemaparan S. aureus dengan bahan antibakteri seperti yang ditunjukkan pada Gambar 4 dan terbentuknya fluoresensi merah setelah pewarnaan dengan PI (Gambar 5b).

\section{KESIMPULAN}

Penggunaan getah pepaya kering pada pembuatan dangke selain berfungsi sebagai bahan penggumpal juga berperan sebagai komponen yang mampu menahan pertumbuhan $S$. aureus bila dibandingkan dengan kontrol sehingga tidak menjadi lebih banyak selama penyimpanan 24 jam pada suhu ruang $\left(27-30^{\circ} \mathrm{C}\right)$. Papain dan komponen non-proteolitik getah pepaya yang diekstraksi dengan etanol juga menunjukkan 
kemampuan menghambat pertumbuhan S. aureus hingga $90 \%$ pada media TSB. Mekanisme penghambatan S. aureus oleh getah pepaya kering, papain, dan ekstrak etanol getah pepaya adalah dengan menyebabkan kerusakan pada membran sel bakteri yang ditunjukkan dengan peningkatan nilai absorbansi $260 \mathrm{~nm}$ dan pengikatan PI oleh DNA S. aureus yang diamati dengan mikroskop fluoresens.

\section{UCAPAN TERIMA KASIH}

Penelitian ini dapat terlaksana atas bantuan dana penelitian dari Hibah Penelitian Unggulan Perguruan Tinggi tahun 2013 dengan nomor kontrak 62/IT3.41.2/LI/SPK/2013, Direktorat Jenderal Pendidikan Tinggi Kementerian Pendidikan dan Kebudayaan.

\section{DAFTAR PUSTAKA}

Adejuwon AO, Agbaje EO, Idika N. 2011. Antifungal and antibacterial activities of aqueous and methanolic root extracts of Carica papaya linn. (Caricaceae). Int Res J Microbiol 2: 270-277.

Akujobi CN, Ofodeme CN, Enweani CA. 2010. Determination of antibacterial activity of Carica papaya (paw-paw) extracts. Niger J Clin Pract Nigerian 13: 55-57.

Aravind G, Bhowmik D, Duraivel S, Harish G. 2013. Traditional and Medicinal Uses of Carica papaya. J Med Plant Stu 1: 715.

Aref HL, Salah KBH, Chaumont JP, Fekih A, Aouni M, Said K. 2010. In vitro antimicrobial activity of four Ficus carica latex fractions against resistant human pathogens (Antimicrobial activity of Ficus carica latex). Pak J Pharm Sci 23: 53-58.

Arekemase MO, Kayode RMO, Ajiboye AE. 2011. Antimicrobial activity and phytochemical analysis of Jatropha curcas plant against some selected microorganisms. Int J Bio 3: 52-59.

Ashok CD, Prachu BM, Umesh JU, Manohar PV. 2011. Antibacterial and antioxidant activity of plant latex. J Pharm Res 4: 406-407.

[BAM] Bacterial Analytical Manual . 2003. Chapter 3 Aerobic plate count. [FDA] Food and Drug Administration. www.fda.gov. [30 Januari 2013].

Baskaran C, Ratha bai V, Velu S, Kumaran K. 2012. The efficacy of Carica papaya leaf extract on some bacterial and a fungal strain by well diffusion method. Asian Pac J Trop Dis 2: S658-662. DOI: 10.1016/S2222-1808(12)60239-4.

Bergmeyer HU (ed). 1984. Methods of Enzymatic Analysis, Vol V. $3^{\text {rd }}$ edition. 121. Verlag Chemie, Weinheim.

Berney M, Hammes F, Bosshard F, Weilenmann H, Egli T. 2007. Assessment and interpretation of bacterial kit in combination with flow cytometry viability by using the LIVE/DEAD BacLight. Appl Environ Microb 73: 3283-3290. DOI: 10.1128/AEM.02750-06.

Carson CF, Mee BJ, Riley TV. 2002. Mechanism of action of Malaleuca alternifolia (tea tree) oil on Staphylococcus aureus determined by time-kill, lysis, leakage, and salt tolerance assays and electron microscopy. Antimicrob Agents Ch 46: 1914-1920. DOI: 10.1128/AAC.46.6.1 9141920.2002.

Chaiwut P, Nitsawang S, Shank L, Kanasawud P. 2007. A comparative study on properties and proteolytic components of papaya peel and latex proteases. Chiang Mai J Sci 34: 109-118.

Cosentino S, Tuberoso CIG, Pisano B, Satta M, Mascia V, Arzedi E, Palmas F. 1999. In-vitro antimicrobial activity and chemical composition of sardinian Thymus essential oils. Lett Appl Microb 29: 130-135.

Cowan MM. 1999. Plant products as antimicrobial agents. Clinical Microbiology Reviews 12: 564-582.

De Olievera LP, Barros LSS, Silva VC, Cirqueria MG. 2011. Study of Staphylococcus aureus in raw and pasteurized milk consumed in the Reconcavo area of the State of Bahia, Brazil. J Food Process Technol 2: 1-5. DOI: 10.4172/21577110.1000128.

El Moussaoui A, Nijs M, Paul C, Wintjens R, Vincentelli J, Azarkan M, Looze Y. 2001. Review : Revisiting the Enzyme Storage in the Laticifers of Catica papaya in the Contxt of their possible participation in the plant defence mechanism. Cell Mol Life Sci 58: 556-570. DOI: 10.1007/PL000 00881.

Eshamah H, Han I, Naas H, Rieck J, Dawson P. 2013. Bactericidal effects of natural tenderizing enzymes on Escherichia coli and Listeria monocytogenes. J Food Res2: 8-18. DOI: 10.5539/jr.v2n1p8.

Geantaresa E, Supriyanti FMT. 2010. Pemanfaatan ekstrak kasar papain sebagai koagulan pada pembuatan keju Cottage menggunakan bakteri. J Sains dan Teknologi Kimia 1: $38-43$

Giao MS, Wilks SA, Azevedo NF, Vieira MJ. 2009. Validation of SYTO 9/propidium iodide uptake for rapid detection of viable but noncultivable legionella pneumophila. Microb Ecol 58: 56-62. DOI: 10.1007/s00248-008-9472-x.

Krishna KL, Paridhavi M, Patel JA. 2004. Review on nutritional, medicinal and pharmacological properties of Papaya (Carica papaya Linn.). Nat Prod Rad 4: 364-373.

Liu H, Du Y, Wang X, Sun L. 2004. Chitosan kills bacteria through cell membrane damage. Int J Food Microbiol 95: 147-155. DOI: 10.1016/j.ijfoodmicro.2004.01.022

Nitsawang S, Hatti-Kaul R, Kanasawud P. 2006. Purification of papain from Carica papaya Latex: aqueous two-phase extraction versus two-step salt precipitation. Enzyme Microb Tech 39: 1103-1107. DOI: 10.1016/j.enzmictec.2006. 02.013.

Oonmetta-aree J, Suzuki T, Gasaluck P, Eumkeb G. 2006. Antimicrobial properties and action of galangal (Alpina galangal Linn.) on Staphylococcus aureus. LWT - Food Sci Technol 39: 1214-1220. DOI: 10.1016/j.Iwt.2005.06.015.

Otto CC, Cunningham TM, Hansen MR, Haydel SE. 2010 Effects of antibacterial mineral leachates on the cellular ultrastructure, morphology, and membrane integrity of Escherichia coli and methicillin-resistant Staphylococcus aureus. Annals of Clinical Microbiology and Antimicrobials 9: 1-13. DOI: 10.1186/1476-0711-9-26. 
Rhoades J, Roller S. 2000. Antimicrobial actions of degraded and native chitosan against spoilage organisms in laboratory media and foods. Appl Environ Microb 66: 80-86. DOI: 10.1128/AEM.66.1.80-86.2000.

Santo CE, Lam EW, Elowsky CG, Quaranta D, Domaille DW, Chang CJ, Grass G. 2011. Bacterial killing by dry metallic copper surfaces. Appl Environ Microb 77: 794-802. DOI: 10.1128/AEM.01599-10.

Seenivasan R, Roopa L, Gheeta S. 2010. Investigation on purification, charachterization and antimicrobial activity of enzyme papain from Carica papaya Linn. J Pharm Res 3: 1092-1095.

Singh P, Prakash A. 2010. Prevalence of coagulase positive pathogenic Staphylococcus aureus in milk and milk products collected from unorganized sector of Agra. Acta Argiculturae Slovencia 96: 37-41.

Wang J, Sun B, Cao Y, Tian Y, Li X. 2008. Optimisation of ultrasound-assisted extraction of phenolic compounds from wheat bran. Food Chem 106: 804-810. DOI: 10.1016/j.food chem.2007.06.062. 